\title{
Development of a guided imagery program for patients admitted to palliative care units
}

Construção de um programa de imaginação guiada para doentes internados em unidades de cuidados paliativos

Construcción de un programa de imaginación guiada para pacientes internados en unidades de cuidados paliativos

Adriana Coelho*; Vítor Parola**; Olga Fernandes***; Ana Querido****; João Apóstolo*****

\section{Abstract}

Background: Guided imagery (GI) is being increasingly used as a non-pharmacological intervention in different clinical settings. However, GI intervention programs have not yet been developed and adapted to patients admitted to palliative care units, which impedes their implementation. Thus, the need emerges to develop and validate a GI program.

Objective: To develop and validate a GI program.

Methodology: A descriptive study was conducted following the guidelines of the Medical Research Council for the development of complex interventions in 3 phases: identifying the evidence base, identifying/developing appropriate theory, modelling process and outcomes.

Results: The development process resulted in a program consisting of 2 GI sessions to be implemented in the same week. Preliminary results on the implementation of a GI session suggest that the intervention is effective in increasing comfort.

Conclusion: The characteristics of the GI program proved to be adjusted to the context and target population. The effectiveness of the GI program will be tested in a quasi-experimental study.

Keywords: palliative care; nursing; palliative nursing; guided imagery; research design

\section{Resumo}

Enquadramento: Uma das intervenções não farmacológicas cada vez mais implementada em diferentes contextos clínicos é a imaginação guiada (IG). Porém, não existem programas de intervenção de IG desenvolvidos e adaptados aos doentes admitidos em unidades de cuidados paliativos, o que impossibilita a sua implementação. Assim, emerge a necessidade de se desenvolver e validar um programa de IG.

Objetivo: Construir e validar um programa de IG.

Metodologia: Estudo descritivo, seguindo as diretrizes para desenvolvimento de intervençóes complexas do $\mathrm{Me}$ dical Research Council que consiste em 3 fases: identificação da evidência existente, identificação e/ou desenvolvimento de teoria, modelagem do processo e resultados.

Resultados: $\mathrm{O}$ processo de desenvolvimento resultou num programa composto por 2 sessóes de IG a serem implementadas numa mesma semana. Resultados provisórios relativamente à implementação de uma sessão de IG sugerem que a intervençáo é eficaz na melhoria do conforto. Conclusão: O programa de IG demonstrou ter características ajustadas ao contexto e populaçáo-alvo. A eficácia do programa será provada num estudo quasi-experimental, a desenvolver.

Palavras-chave: cuidados paliativos; enfermagem; enfermagem de cuidados paliativos; imagens guiadas; projetos de pesquisa

*MSc., Doctoral student in Nursing Sciences, Abel Salazar Biomedical Sciences Institute. Guest Assistant Nursing School of Coimbra, Health Sciences Research Unit: Nursing Portugal Centre for Evidence-B sed Practice: A JBI Centre of Excellence, 3046-851, Coimbra, Portugal [adriananevescoelho@esenf: ptl. Contribution to the article: study design; methodology planning data collection, processing and analysis; article writing.

analysis; article witung. tant, Nursing School of Coimbrn Health Sciences Research Unit: Nursing Portugal Centre for Evidence-Based Practice: A JBI Centre of Fxcellence, 3046-851, Coimbm Portol [vitorparol Corfer

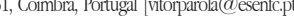
Contribution to the article: methodology planning; study design; article revision.

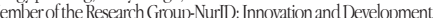
in Nursing -CINTESTS - Center for Health Technology and Services Research - FMIP Nursing School of Porto, 4200-072, Porto, Portugal [olgafernandes@esenf pt]. Contribution to the article: methodologr planning; study design; methodological supervision; article revision.

*****Ph.D., Adjunct Professor, School of Health, Polvtechnic Institute of Leiria, 2411-901, Leiria, Portugr [ana.querido@ipleinia pt]. Contribution to the article: methodological supervision; article revision. anaquerido@ipleiria.pt).Contribution to the article: methodological supervision; article revision. Unit: Nursing, Portugal Centre for Evidence-Based Practice: A JBI Centre of Excellence, 3046-851, Coinbra Portugal [apostolo@esenf pt]. Contribution to the article: methodology planning. methodological supervision; article revision.

\section{Resumen}

Marco contextual: Una de las intervenciones no farmacológicas que se implementan cada vez más en diferentes contextos clínicos es la imaginación guiada (IG). Sin embargo, no existen programas de intervención de IG desarrollados y adaptados a los pacientes admitidos en unidades de cuidados paliativos, lo que imposibilita su implementación. De este modo, surge la necesidad de desarrollar y validar un programa de IG.

Objetivo: Construir y validar un programa de IG.

Metodología: Estudio descriptivo, que sigue las directrices para el desarrollo de intervenciones complejas del Medical Research Council, que consiste en 3 fases: identificación de las pruebas existentes, identificación y/o desarrollo de la teoría, modelado del proceso.

Resultados: El proceso de desarrollo dio lugar a un programa compuesto por 2 sesiones de IG para implementarse en una misma semana. Los resultados provisionales de la implementación de una sesión de IG sugieren que la intervención es eficaz en la mejora del confort.

Conclusión: El programa de IG demostró que tiene características ajustadas al contexto y la población objetivo. La eficacia del programa se probará en un estudio cuasiexperimental que se desarrollará más adelante.

Palabras clave: cuidados paliativos; enfermería; enfermería de cuidados paliativos; imagenes guiadas; proyectos de investigación 


\section{Introduction}

The increase in average life expectancy and the high prevalence of chronic progressive diseases are having an increasing impact on the organization of health care systems and the need for palliative care units (PCU; Comissão $\mathrm{Na}$ cional de Cuidados Paliativos, 2016). According to the World Health Organization (2002), palliative care (PC) is an approach aimed at improving the quality of life of patients and their families facing problems associated with an incurable and/or severe disease with limited prognosis, through the prevention and relief of suffering. These are active total care where aggressive therapeutic measures are replaced by intensive comfort care.

Comfort is the purpose of PC and the nursing care process. It is defined by Kolcaba (1995) as the state of having the needs for relief, ease, and transcendence met in four contexts: physical, sociocultural, psychospiritual, and environmental.

To this end, non-pharmacological interventions have been increasingly developed and implemented in PC, both independently and in combination with other therapeutic approaches, which has also been reflected in improved patient comfort (Coelho, Parola, Cardoso, Escobar-Bravo, \& Apóstolo, 2017).

However, the need for hiring outside professionals with specific training, the lack of scientific evidence on the effectiveness of interventions (Osaka et al., 2009), and the institutional costs involved in their implementation are some of the barriers to their implementation (Olotu, Brown, Barner, \& Lawson, 2014).

Guided imagery (GI) is being increasingly used as a non-pharmacological intervention in different clinical settings.

GI is the process of intentional use of mental images and sensory attributes, resulting from imagination or memory, to achieve a desired therapeutic outcome (Naparstek, 1994). The person's involvement with the mental images is so intense that the body tends to respond as it would to a genuine external experience, which has profound psychophysiological consequences (Apóstolo, 2010; Hart, 2008). It is a simple, low-cost intervention that can be implemented by nurses and that requires little effort of patients.
The literature shows that the intervention with GI is associated with increased comfort in women with breast cancer (Kolcaba \& Fox, 1999), in psychiatric patients (Apóstolo \& Kolcaba, 2009), among others.

In PC, however, a scoping review conducted by Coelho et al. (2017) found no studies on the effects of GI in comfort, which clearly limits its implementation. Based on the above-mentioned studies, the potential effects of GI in PC should not be underestimated. If this intervention proves to be effective in this context, its implementation can result in a significant increase in the comfort level of patients admitted to PCU.

In this way, the need emerged to develop and validate a GI program for patients admitted to PCU. The Medical Research Council guidelines and recommendations for the development of complex interventions were followed (Craig et al., 2008). This article aims to describe the different stages of this process.

\section{Background}

No GI program has yet been designed specifically for PC (Coelho et al., 2017). Hence, to address this challenge, a GI program was developed and validated for patients admitted to PCU.

In the method proposed by the Medical Research Council, complex interventions are characterized by a significant number of interactions between components; difficulty of behaviors required by those delivering or receiving the intervention; a significant number of groups or organizational levels targeted by the intervention; variability of outcomes; and degree of flexibility or tailoring of the intervention permitted (Craig et al., 2008). When applied to a group of people, complex interventions produce one or several outcomes, with health gains for these people.

Their development should be based on identifying the evidence base; identifying/developing appropriate theory; and modeling process and outcomes (Craig et al., 2008).

\section{Research question}

What is the validity of the GI program being developed for patients admitted to PCU? 


\section{Methodology}

Given the nature of the object under analysis, a descriptive mixed-methods study was conducted which indicates the different phases of development and validation of a GI program based on the above-mentioned recommendations of the Medical Research Council (Craig et al., 2008).

\section{Phase I - Identifying the evidence base}

This phase consisted of identifying the existing evidence on similar interventions and the methods used to assess them (Craig et al., 2008). Thus, the strengths and limitations of existing programs were identified, starting from the evidence emerging from primary studies (Apóstolo \& Kolcaba, 2009; Hosseini, Tirgari, Forouzi, \& Jahani, 2016; Kolcaba \& Fox, 1999; Spiva et al., 2015) and systematic literature reviews (Roffe, Schmidt, \& Ernst, 2005; Van Kuiken, 2004), which confirmed the therapeutic potential of GI for promoting comfort in different clinical areas. A scoping review was also conducted with the purpose of mapping the non-pharmacological interventions to provide comfort in PC. This scoping review revealed a lack of GI programs adapted to PC settings and provided relevant information about other complex interventions implemented in this context, their characteristics, the characteristics of the target population, as well as the methods used to assess them (Coelho et al., 2017).

\section{Phase II - Identifying/developing appro- priate theory}

This phase consisted in the development of a theoretical understanding of existing evidence and theory, supplemented by primary research (Craig et al., 2008). Thus, the literature on GI, including scripts suggested by renowned authors in this area (Apóstolo, 2007), and the literature about comfort, including Katherine Kolcaba's theory of comfort (1995), were analyzed. A qualitative phenomenological study (Coelho, Parola, Escobar-Bravo, \& Apóstolo, 2016) was conducted to understand the comfort and discomfort experiences of patients admitted to PCU.

\section{Phase III - Modeling process and outcomes} This phase consisted of gradually modeling the intervention, before a full-scale evalu- ation. It was composed of three sub-phases (Craig et al., 2008): preliminary, field testing, and consensus conference.

\section{Preliminary}

In this sub-phase, the analysis of the information resulting from the two first phases (Identifying the evidence base and Identifying/developing appropriate theory) supported the first version of the GI script. Six experts (nursing graduates, master's and doctoral degree holders, and doctoral students in areas related to PC, comfort, and GI) were asked to analyze the first version. The consulting process focused on the acceptability of the first version of the GI script to be applied to patients admitted to PCU. The experts were asked to give their opinion on the relevance and feasibility of the development and implementation of this program, the need for GI interventions in PC settings, the barriers to their implementation, as well as to make any relevant suggestions. A questionnaire was also applied to each expert with the purpose of obtaining their opinions on the clarity of instructions as well as their adaptation to patients admitted to PCU. The answers were based on a 5-point Likert scale, ranging from strongly agree to strongly disagree. Based on collected data, the script was revised, resulting in a second version.

\section{Field testing}

Taking into account that the data collected in the preliminary sub-phase were limited to the experts' professional and academic experience, which resulted in a purely theoretical analysis of the GI program, the need emerged to model the intervention script to the practical context. Thus, the second version of the GI script was audio recorded aimed at optimizing its content, adjusting speech fluency and the time period between each instruction on respiratory exercises, muscle relaxation, and formation of mental images, and validating the adequacy of the intervention to the target population through field testing. This second version was audio recorded and, subsequently, tested in two nurses, who had been working at the PCU for more than one year and voluntarily accepted to participate in the study, and in two patients, who had been admitted to the PCU and met the inclusion and exclusion criteria listed in Table 1. 
Table 1

Inclusion and exclusion criteria of patients admitted to the PCU

\begin{tabular}{ll}
\hline Inclusion criteria & Exclusion criteria \\
\hline $\begin{array}{l}\text { Being in good clinical conditions to participate } \\
\text { in the intervention program; }\end{array}$ & Patients with cognitive impairment; \\
Being hospitalized at the unit for at least 2 days; & End-of-life patients. \\
Accepting to participate in the study. & \\
\hline
\end{tabular}

The sessions with the nurses took place in a private room of the PCU. The sessions with the patients took place in each patient's room. All sessions were conducted by the principal investigator and lasted 13 minutes.

After field testing, a questionnaire was applied to the participants, which had been developed and previously used by Apóstolo (2007) in a similar study, about the following topics: recording quality, voice, sound, and background music; clarity of instructions on breathing and relaxation; relaxation period; ability to relax; ability to follow the mental images; and the time allowed for creating and visualizing each image. The answers were rated on a 5-point Likert scale, ranging from strongly agree to strongly disagree.

In addition, patients were also administered a Comfort Visual Analog Scale (VAS), and relevant qualitative data were collected.

Based on these data, a third version of the GI script was developed.

\section{Consensus conference}

Finally, the consensus conference strategy was applied in which the different versions of the GI script, the quantitative and qualitative results of field testing, and all comments and suggestions were submitted to an expert panel for analysis and discussion. In this panel, the different versions of the GI script were compared, and the significant changes and potential program strengths and limitations were discussed. This sub-phase completed the process.

With regard to the ethical and legal principles, the authors requested permission from the Ethics Committee of the Hospital Arcebispo João Crisóstomo of Cantanhede (08/02/2017) to conduct the study. Throughout the different phases, all procedures were followed to respect the participants' anonymity, confidentiality, and informed consent.

\section{Results}

The results obtained in each methodological phase will be described below, underlining the different contributions obtained for the analysis and redesign of the program.

The analysis of data from Phases I (Identifying the evidence base) and II (Identifying/ developing appropriate theory) resulted in the first version of the GI program. Thus, the intervention program will include two GI sessions which, due to clinical instability and vulnerability, will be implemented in the same week.

The content of the script is divided into three main sections: (1) General indications that include the name of the technique and instructions on the attitude and posture to be adopted; (2) Breathing and muscle relaxation exercises to eliminate any existing tension. Therefore, participants are encouraged to tale slow deep breaths, as well as to relax the head, face, eyelids, lips, back, abdomen, legs, and feet. By following these instructions, participants enter into a deeper state of relaxation, being encouraged to adopt a comfortable position and free their mind from negative thoughts; (3) Induction of a series of mental images. With the purpose of leading the patient to create comforting and soothing mental images, the assumptions underlying the development of the script were based mostly on positive imagination. Thus, the mental images include a (real or imaginary) special place for the patients where they can feel secure, comfortable, safe, and free. Patients are asked to elaborate a sequence of 
mental images, evoking natural scenarios in which they can move around, focusing particularly on the sensory component of these scenarios through sight, hearing, smell, and touch. Indeed, the results of the phenomenological study (Coelho et al., 2016) carried out in Phase II suggest that the lack of a green space outside the PCU intended for patients can create a feeling of discomfort by depriving them of their freedom.

Given that several authors find it important to suggest a path to communicate with the inner self, or simply for a person to walk in the scenario, this instruction was included in the script (Payne, 2003; Samuels, 2003).

Therefore, after the breathing and muscle relaxation exercises, patients are asked to "imagine a perfect place where you would like to be right now", "a place where you feel comfortable ... A place where you feel secure, safe, and free". To choose a place that better fits their preferences, they are given the following possibilities: "It could be a clearing in the woodland . . . a valley . . . a meadow in the countryside . . . or a garden full of flowers." Subsequently, patients are asked to pay attention to the sensory content of the environment, with instructions such as: "Now take a moment to listen ... What do you hear? Perhaps you can hear the birds singing ... or the leaves rustling."

Then, patients are asked to imagine walking down a path to meet with someone special "Who would you like to be with? Imagine . .. Sit calmly next to this person ... This person can hear you and help you feel better . .. What would you like to tell him/her? Feel free to tell him/her whatever you want".

After having experienced this imaginary encounter, patients are asked to leave that place and bring with them the good experiences, coming out of the relaxation state.

Finally, patients are asked to consider the PCU as a place where the professionals can help them feel comfortable.
Phase III (Modeling) was composed of three sub-phases: preliminary, field testing, and consensus conference.

In the preliminary sub-phase, the experts found that the intervention was relevant and feasible and that the participants' weakness could be the main limitation to its implementation. For this reason, they found it important to conduct two GI sessions in the same week.

The experts strongly or somewhat agreed with all statements, with the exception of the adaptation of the breathing and muscle relaxation instructions to the patient with advanced disease, in which they showed a lower degree of agreement (Table 2).

Among the experts' suggestions are the need to simplify the breathing and relaxation exercises due to the "patients' difficulty, due to their frailty and physical weakness, to follow the breathing and relaxation instructions" (Expert No. 2, January, 2017) and "these patients' difficulty in controlling their breathing" (Expert No. 4, January, 2017). Thus, these instructions were simplified and instructions such as "breathe slowly and deeply" were replaced by "breathe in and out calmly", "take the time you need", since the word slowly implies control over breathing.

In their suggestions, the experts also underlined that "The majority of people may already have lost their functional skills and the ability to walk". In these cases, the instruction "prepare to take a walk", without reinforcing the bodily sensations of lightness and floating, can force the patient to be confronted with the reality of disability and leave the state of imagination". Thus, the instruction "prepare to take a walk" "could be reinforced with the imagination that the body is light and floating." (Expert No. 5, January, 2017). Given this suggestion, prior to the instruction "imagine that you are going for a walk", patients were asked to imagine that their body "was light and floating". 
Table 2

Program assessment by experts in Phase II - preliminary sub-phase

\begin{tabular}{|c|c|c|c|c|c|}
\hline Question & $\begin{array}{l}\text { Strongly } \\
\text { agree }\end{array}$ & $\begin{array}{l}\text { Somewhat } \\
\text { agree }\end{array}$ & Agree & $\begin{array}{l}\text { Somewhat } \\
\text { disagree }\end{array}$ & $\begin{array}{l}\text { Strongly } \\
\text { disagree }\end{array}$ \\
\hline The breathing instructions are clear & $33 \%$ & $67 \%$ & $0 \%$ & $0 \%$ & $0 \%$ \\
\hline $\begin{array}{l}\text { The breathing instructions are adapted } \\
\text { to the patient admitted to the PCU }\end{array}$ & $0 \%$ & $50 \%$ & $50 \%$ & $0 \%$ & $0 \%$ \\
\hline The relxation instructions are clear & $16.7 \%$ & $83.3 \%$ & $0 \%$ & $0 \%$ & $0 \%$ \\
\hline $\begin{array}{l}\text { The relaxation instructions are adapted } \\
\text { to the patient admitted to the PCU }\end{array}$ & $0 \%$ & $33.4 \%$ & $66.6 \%$ & $0 \%$ & $0 \%$ \\
\hline The GI instructions are clear & $33.3 \%$ & $66.7 \%$ & $0 \%$ & $0 \%$ & $0 \%$ \\
\hline $\begin{array}{l}\text { The GI instructions are adapted to the } \\
\text { patient admitted to the PCU }\end{array}$ & $33.3 \%$ & $66.7 \%$ & $0 \%$ & $0 \%$ & $0 \%$ \\
\hline
\end{tabular}

In the field testing sub-phase, in line with the experts' assessment (preliminary sub-phase), both nurses and patients admitted to PCU reported that the implementation of this type of interventions in the PCU is an added value for patients because it could increase their comfort, as well as for nurses because it is a comfort intervention. Nurses also agreed with the im- plementation of two sessions in the same week. In relation to the questionnaire, all participants strongly or somewhat agreed with all statements, with the exception of the time allowed for each image, in which there was a lower degree of agreement since only one participant (nurse) somewhat agreed with that statement (Table 3).

Table 3

Program assessment by nurses and patients admitted to a PCU (Field testing sub-phase)

\begin{tabular}{|c|c|c|c|c|c|}
\hline & $\begin{array}{c}\text { Strongly } \\
\text { agree }\end{array}$ & $\begin{array}{c}\text { Somewhat } \\
\text { agree }\end{array}$ & Agree & $\begin{array}{c}\text { Somewhat } \\
\text { disagree }\end{array}$ & $\begin{array}{l}\text { Strongly } \\
\text { disagree }\end{array}$ \\
\hline Overall, the recording helped me relax & $100 \%$ & $0 \%$ & $0 \%$ & $0 \%$ & $0 \%$ \\
\hline The voice is relaxing & $75 \%$ & $25 \%$ & $0 \%$ & $0 \%$ & $0 \%$ \\
\hline The music helped me to relax & $100 \%$ & $0 \%$ & $0 \%$ & $0 \%$ & $0 \%$ \\
\hline The sound volume made it difficult to relax & $0 \%$ & $0 \%$ & $0 \%$ & $0 \%$ & $100 \%$ \\
\hline The breathing instructions are clear & $0 \%$ & $100 \%$ & $0 \%$ & $0 \%$ & $0 \%$ \\
\hline The breathing instructions are easy to follow & $25 \%$ & $75 \%$ & $0 \%$ & $0 \%$ & $0 \%$ \\
\hline The relaxation instructions are clear & $25 \%$ & $75 \%$ & $0 \%$ & $0 \%$ & $0 \%$ \\
\hline The relaxation instructions are easy to follow & $0 \%$ & $100 \%$ & $0 \%$ & $0 \%$ & $0 \%$ \\
\hline The time allowed for relaxation is enough & $75 \%$ & $25 \%$ & $0 \%$ & $0 \%$ & $0 \%$ \\
\hline The mental images helped me to relax & $25 \%$ & $75 \%$ & $0 \%$ & $0 \%$ & $0 \%$ \\
\hline It was easy to follow the suggested images & $0 \%$ & $75 \%$ & $25 \%$ & $0 \%$ & $0 \%$ \\
\hline The time allowed for each image is enough & $0 \%$ & $25 \%$ & $75 \%$ & $0 \%$ & $0 \%$ \\
\hline
\end{tabular}


Participants also suggested that the script was not audio recorded because then the instructions and time elapsed between each instruction could be customized and adjusted to each patient, leaving the possibility to repeat the instructions, if needed, without having to rewind the audio.

In addition, nurses suggested that the sea could be used as a comforting mental image given that, according to their experience, some patients ask if they can leave the hospital to see the ocean again, which they are not always allowed to do because of their poor health conditions. It should be noted that the experts (preliminary sub-phase) were concerned about water phobia: "The reference to sounds could include the sound of the water from a distant stream (the fact that it is a distant stream ensures protection for water phobia/discomfort due to fear of drowning)" (Expert No. 5, January, 2017).

As regards the duration of the program, even though one of the experts (preliminary subphase) found it potentially excessive, this opinion did not prevail among the participants in this sub-phase.

In relation to the VAS administered to the patients, both of them improved their level of comfort (VAS before the intervention, 3 and 4; VAS after the intervention, 7 and 8, respectively). The following qualitative comments should be highlighted: "This was the first time in a very long time that I was able to stop thinking about death even for a few minutes" (Participant No. 2, February, 2017), "It was really nice to talk to my mother ... . I even feel less pain" (Participant No. 1, February, 2017). Both quantitative and qualitative data reveal the potential of the intervention. Both patients were interested in repeating the session.

During the consensus conference sub-phase, which was the final phase in the process of development and validation of the GI program, the divergences and convergences found along the different phases and subphases were analyzed. It should be noted that the research group gave special attention to a specific aspect: the suggested mental images about the water, the beach, and the sea.

Although initially the mental image of the sea was not used due to possible water phobia and discomfort for fear of drowning, this opinion did not prevail among the nurses participating in the field testing sub-phase. In fact, they even had a contrary opinion because they believed that the induction of mental images that did not include environments capable of providing a high level of comfort to some patients could be a weakness of the script. It should be noted that the qualitative study (Phase II) showed that the lack of contact with nature (trees, flowers, countryside) led to an experience of discomfort among patients admitted to the PCU.

Based on these results, the third version of the GI script was developed. In addition to including the above-mentioned changes, in its third section (induction of a series of sequential mental images), each participant will, prior to the first session, select the most comforting environment (countryside vs. sea). Both sessions will be accompanied by relaxing music consistent with the selected environment.

Taking into account the pilot participants' suggestion, the intervention will not consist of listening to an audio-recorded script, but will rather be tailored to each participant. Thus, the speed and rhythm of each instruction and, consequently, the duration of each session will be adjusted to each patient. The intervention will be implemented by the principal investigator (nurse).

\section{Discussion}

The increase in average life expectancy and the high prevalence of chronic diseases call for the development of complex interventions which result in patient comfort. Given the lack of GI scripts adjusted to PC settings, the GI script, which was developed and validated, emerges as a potential contribution to clinical practice and comfort gains for patients admitted to PCU.

The GI script development and validation process is recommended by the Medical Research Council (Craig et al., 2008) as a way of safeguarding researchers from facing limitations related to acceptability, compliance, delivery of the intervention, retention of participants, and smaller-than-expected results, 
which can weaken the evaluation of an intervention's effectiveness.

The development of this program was based on previously existing evidence, the production of new evidence, the assessment of experts with training in the area and extensive experience in the implementation of therapeutic interventions, as well as on the field testing conducted with patients admitted to PCU; it went beyond the theoretical component and gave patients an opportunity to express their opinion. The result is a program that is adjusted, adapted, and appropriate to the comfort needs of patients admitted to PCU.

The consensus among experts, nurses, and patients hospitalized in the PCU about the relevance of the intervention, the quantitative and qualitative evaluation during the field testing sub-phase, and the obtained results point towards the likely effectiveness of the intervention in terms of comfort.

These data are consistent with the results found in the literature which reveal the potential effectiveness of GI in increasing comfort, although they have been obtained in other clinical areas.

Nevertheless, and even though the implementation of guidelines by the Medical Research Council for the development of complex interventions is a best practice in clinical research, this process does not ensure the effectiveness of the intervention. Therefore, as proposed by the Medical Research Council (Craig et al., 2008), the intervention program has to be evaluated on a larger scale with the purpose of assessing its actual contribution to increasing comfort in patients admitted to PCU.

\section{Conclusion}

Based on the Medical Research Council guidelines for the development of complex interventions, a program was designed and adapted to the comfort needs of patients admitted to PCU. This program consists of two GI sessions to be implemented in the same week.

Each session is composed of a process of relaxation and induction of mental images, complemented by music.

The validity of the program is supported by the consensus among experts, nurses, and patients admitted to the PCU about the relevance of the intervention, and the positive quantitative and qualitative assessment during the field testing phase.

This program has implications for clinical practice and research through its transferability and possible use in clinical practice.

\section{Acknowledgments}

The authors acknowledge the support of the Health Sciences Research Unit: Nursing (UICISA: E) of the Nursing School of Coimbra.

\section{References}

Apóstolo, J. L. (2007). O imaginário conduzido no conforto de doentes em contexto psiquiátrico (Doctoral thesis). Universidade do Porto, Instituto de Ciências Biomédicas Abel Salazar, Portugal.

Apóstolo, J. L. (2010). O conforto pelas imagens mentais na depressão, ansiedade e stress. Coimbra, Portugal: Imprensa da Universidade de Coimbra/ Escola Superior de Enfermagem de Coimbra.

Apóstolo, J. L., \& Kolcaba, K. (2009). The effects of guided imagery on comfort, depression, anxiety, and stress of psychiatric inpatients with depressive disorders. Archives of Psychiatric Nursing, 23(6), 403-411. doi:10.1016/j. apnu.2008.12.003

Coelho, A., Parola, V., Cardoso, D., Escobar-Bravo, M., \& Apóstolo, J. (2017). Use of non-pharmacological interventions for comforting patients in palliative care: A scoping review. JBI Database of Systematic Reviews and Implementation Reports, 15(7), 1867-1904. doi:10.11124/JBISRIR-2016-003204

Coelho, A., Parola, V., Escobar-Bravo, M., \& Apóstolo, J. (2016). Comfort experience in palliative care: A phenomenological study. BMC Palliative Care, 15(1), 71 79. doi:10.1186/s12904-016-0145-0

Comissão Nacional de Cuidados Paliativos. (2016). Plano Estratégico Para O Desenvolvimento Dos Cuidados Paliativos Biénio 2017-2018.

Craig, P., Dieppe, P., Macintyre, S., Michie, S., Nazareth, I., \& Petticrew, M. (2008). Developing and evaluating complex interventions: The new medical research council guidance. BMJ, 337, a1655. doi:10.1136/bmj.a1655

Hart, J. (2008). Guided imagery. Alternative and Complementary Therapies, 14(6), 295-299. doi:10.1089/ act.2008.14604 
Hosseini, M., Tirgari, B., Forouzi, M. A., \& Jahani, Y. (2016). Guided imagery effects on chemotherapy induced nausea and vomiting in Iranian breast cancer patients. Complementary Therapies in Clinical Practice, 25, 8-12. doi:10.1016/j.ctcp.2016.07.002

Kolcaba, K. Y. (1995). Comfort as process and product, merged in holistic-nursing art. Journal of Holistic Nursing, 13(2), 117-131. doi:10.1177/089801019501300203

Kolcaba, K. Y., \& Fox, C. (1999). The effects of guided imagery on comfort of women with early stage breast cancer undergoing radiation therapy. Oncology Nursing Forum, 26(1), 67-72.

Naparstek, B. (1994). Staying well with guided imagery. New York, NY: Warner Books.

Olotu, B. S., Brown, C. M., Barner, J. C., \& Lawson, K. A. (2014). Factors associated with hospices' provision of complementary and alternative medicine. The American Journal of Hospice \& Palliative Care, 31(4), 385-391. doi:10.1177/1049909113489873

Osaka, I., Kurihara, Y., Tanaka, K., Nishizaki, H., Aoki, S., \& Adachi, I. (2009). Attitudes toward and current practice of complementary and alternative medicine in Jap- anese palliative care units. Journal of Palliative Medicine, 12(3), 239-244. doi:10.1089/jpm.2008.0215

Payne, R. A. (2003). Técnicas de relaxamento: Um guia prático para profissionais de saúde (2a ed.). Loures, Portugal: Lusociência.

Roffe, L., Schmidt, K., \& Ernst, E. (2005). A systematic review of guided imagery as an adjuvant cancer therapy. Psycho-Oncology, 14(8), 607-617. doi:10.1002/pon.889

Samuels, M. (2003). Healing with the mind's eye: Haw toy use guided imagery and visions to heal body, mind and spirit. New Jersey, NJ: John Wiley \& Sons.

Spiva, L., Hart, P. L., Gallagher, E., McVay, F., Garcia, M., Malley, K., ... Smith, N. (2015). The effects of guided imagery on patients being weaned from mechanical ventilation. Evidence-Based Complementary and Alternative Medicine, 2015, 802865. doi:10.1155/2015/802865

Van Kuiken, D. (2004). A meta-analysis of the effect of guided imagery practice on outcomes. Journal of Holistic Nursing, 22(2), 164-179. doi:10.1177/0898010104266066

World Health Organization. (2002). National cancer control programmes: Policies \& managerial guidelines ( $2^{\text {nd }} \mathrm{ed}$.). Geneva, Switzerland: Author. 
